\title{
PENGARUH SIFAT MATERIALISME, MOTIVASI HEDONIK TERHADAP IMPULSIVE BUYING DAN KECENDERUNGAN COMPULSIVE BUYING SECARA ONLINE DI KALANGAN MAHASISWA UNIVERSITAS MATARAM
}

\author{
1) Rini Anggriani* \\ 2) Handry Sudiartha Athar**
}

\begin{abstract}
This reasearch is aimed at determining the effect of materialism, hedonistic motive on the online impulsive buying and compulsive buying trend in students of Mataram University. This research is causality study using purposive sampling. The populations are all students of Mataram University and the samples are 120 selected students who have made online transaction purchasing fashion at least twice within the last three months. The data were analyzed with Structural Equation Modeling (SEM).

The research showed that variable of materialism has positive and significant effect on the impulsive buying. The materialism also has positive and significant effect on the compulsive buying trend. Hedonistic motive has positive and significant effect on the compulsive buying trend. There is no effect of the impulsive buying on the online compulsive buying trend in the students of Mataram University.
\end{abstract}

Key words: Materialism, Hedonistic Motive, Impulsive Buying, Compulsive Buying Trend.

\section{PENDAHULUAN}

\section{Latar Belakang}

Optimisme Indonesia untuk menjadi "The Largest Digital Economy in the Region" kini mulai terbuka lebar. Menurut Menteri Komunikasi dan Informatika Republik Indonesia Rudi Antara, kunci menuju optimisme tersebut adalah melalui e-commerce (Sumber;http://kominfo.go.id). Pesatnya perkembangan e-commers di Indonesia saat ini, tidak terlepas terus meningkatnya jumlah pengguna internet atau "netters" di Indonesia. Internet kini sudah menjadi kebutuhan rutin yang dapat menunjang segala aktivitas bagi setiap penggunanya. Melalui internet, konsumen mendapatkan banyak kemudahan dalam mengakses segala sumber informasi, kemudahan bertransaksi, dan berinteraksi termasuk salah satunya melakukan aktivitas belanja secara Online.

Hasil survei dari Asosiasi Penyelegara Jasa Internet Indonesia (APJII) pada tahun 2014 jumlah pengguna internet sebesar 83,7 juta pengguna, meningkat di tahun 2015 menjadi 93,4 juta pengguna dan pada tahun 2016 angka ini meningkat lagi menjadi 130 juta pengguna. Dimana, 77 persen pengguna internet tersebut mencari produk dan melakukan belanja Online (Sumber; http//presidenri.go.id). Adapun pengguna internet terbesar di Indonesia berusia 18-25 tahun mencapai 45\% yang didominasi oleh kalangan Wanita 51\% sedangkan Laki-laki 49\%, sementara durasi dalam mengakses internet ratarata pengguna menghabiskan waktu 1 sampai 3 jam perhari (Sumber; www.Money.id). 


\section{$J M M$

Pesatnya pengguna internet juga memicu menjamurnya situs belanja Online yang ada di Indonesia. Akhir tahun 2016, jumlah situs belanja Online berjumlah 150 situs dengan nilai perdaganggan Online tercatat mencapai U\$ 4,89 miliar atau sekitar 69 triliun rupiah, angka tersebut meningkat dari dua tahun sebelumnya yang hanya mencapai 21 triliun.

Fenomena tersebut, secara tidak langsung berdampak pada aktivitas belanja konsumen yang biasanya dilakukan secara Offline-In-Store, kini perlahan mulai bergeser dengan hadirnya situs belanja Online. Keberadaan situs belanja Online kini menjadi alternatif "tempat berbelanja" baru selain pusat perbelanjaan bagi semua kalangan termasuk Mahasiswa. Dengan berbelanja Online, Mahasiswa yang memiliki kesibukan yang padat, waktu luang yang terbatas tidak harus pergi ke pusat perbelanjaan dengan menghabiskan banyak waktu ketika ingin membeli sesuatu, cukup melalui Mobile Phone atau PC/Komputer yang terhubung dengan jaringan internet, dengan satu kali "click mouse" aktivitas belanja dapat dilakukan sehingga menjadi lebih efisien. Kalangan remaja cenderung rentan dan mudah tergoda untuk membeli produk keluaran yang terbaru yang didukung berbagai discount yang cukup "mengiurkan" serta harga yang kompetitif yang ditawarkan oleh pemasar membuat siapa saja mudah untuk cepat "tergoda" dan berusaha mendapatkan barang tersebut dengan segera melakukan pembelian baik impulsive buying apabila dilakukkan dalam jangka waktu yang panjang akan menjadikannya sebagai perilaku pembeli yang berlebihan dan secara terus menerus dalam frekuensi yang tinggi dapat mengarah pada kecenderungan compulsive buying Krisjanti dan Prabowo, (2010). Impulsive buying erat kaitannya dengan psikologis konsumen seperti sifat materialisme dan motivasi hedonik Part et al., 2006 (dalam Prawira, 2015) dan Sun dan $\mathrm{Wu},(2011)$. Salah satu pembelian konsumen yang dapat dipengaruhi faktor psikologis konsumen adalah compulsive buying Cen dkk, (2015).

Menurut Cuneyt \& Gautam, (2004) bahwa psikologis konsumen dapat menjadi faktor utama yang mendorong konsumen untuk melakukan belanja secara Online. Tulkimaz, at all, (2014) dengan mengambil sampel responden di negara Turki, menyatakan ciri kepribadian atau psikologis konsumen seperti sifat materialisme dapat memicu seseorang melakukan impulsive buying secara Online. Selanjutnya dalam penelitian yang sama Floh dan Madlberger, (2013) penelitian terkait impulsive buying secara Online masih sangat jarang diteliti. Jefrey dan Hodge, (2007) sebagian besar penelitian yang telah ada terkait impulsive buying selama ini hanya difokuskan pada gerai Toko dan pusat perbelanjaan. Namun berbeda dengan kajian Burns dan Dick, (2001) bahwa faktor lingkungan seperti pengetahuan internet, pendapatan, dan tingkat pendidikan merupakan prediktor yang paling kuat yang dapat mempengaruhi pembelian konsumen secara Online. Di Indonesia sendiri, masih sangat sedikit penelitian terkait impulsive buying secara Online jika dikaitkan dengan psikologis konsumen seperti sifat materialisme dan motivasi hedonik (Prawira, 2015). Penelitian ini dilakukan salah satunya untuk mengisi gap tersebut.

Menurut O'Guinn dan Faber 1989, (dalam Sari, 2014) kecenderungan compulsive buying adalah perilaku pembelian yang berulang dan akut yang menjadi respon utama untuk menghadapi perasaan atau kejadian yang tidak menyenangkan seperti sedih, depresi, frustrasi, dan lain-lain. Menurut Sari, (2013) perilaku compulsive buying bisa terjadi pada setiap individu yang memiliki kondisi jiwa yang normal. Kecenderungan compulsive buying bisa terjadi pada perilaku pembelian konsumen secara umum, khususnya pada individu yang memiliki daya beli cukup dan cenderung untuk membeli produk dengan frekuensi yang tinggi (Naomi dan Mayasari, 2009). Menurut Cen dkk, 
(2015) kecenderungan compulsive buying dapat juga terjadi pada semua orang, baik pria maupun wanita, tua ataupun muda. Sementara, Gwin et all, 2005 (dalam Soliha, 2010) dalam jangka pendek kecenderungan compulsive buying menjadi suatu pelarian untuk menghilangkan stress dan kejenuhan. Sedangkan dalam jangka panjang compulsive buying dapat memicu terjadinya kebangkrutan, hutang yang menumpuk, keretakan rumah tangga dan lain sebagainya. Kajian empiris yang dilakukan Sari, (2014) penelitian terkait compulsive buying saat ini masih perlu dikaji secara lebih lanjut, terutama bagi sejumlah peneliti dibidang pemasaran maupun konsumsi. O'Guinn dan Faber,(1992) penelitian terkait kecenderungan compulsive buying terus mengalami peningkatan. Sementara menurut Gerlack at all, (2015) kajian terkait compulsive buying selama ini hanya difokuskan pada negara-negara maju dan semakin menarik perhatian peneliti dalam dekade terakhir, sehingga akan menarik untuk mengkaji secara lebih mendalam kecenderungan compulsive buying di negara berkembang.

Produk fashion identik dengan kalangan remaja modern seperti Mahasiswa. Menurut The Nielsen Global Survey of E-Commerce, produk fashion (seperti pakaian, sepatu, jam tanggan dan aksesoris lainnya) termasuk ke dalam urutan lima teratas yang sangat ingin dibeli konsumen secara online (Sumber; $h t t p: / / w w w . n i e l s e n . c o m)$. Produk fashion salah satu jenis produk yang paling banyak diminati. Ini dikarenakan fashion kini sudah menjadi salah satu kebutuhan penting dalam menunjang penampilanserta gaya hidup sehari-hari. Sehingga tidak mengherankan agar terlihat menarik dan fashionable, konsumen rela membayar dengan harga berapapun untuk mendapatkan selera fashion yang diinginkan. Sehigga tidak bisa dipungkiri, di kalangan Mahasiswa kepemilikan barang-barang tertentu sangatlah penting salah satunya adalah produk fashion seringkali sebagai ajang pamer terlebih barang tersebut dikenal cukup "branded". Bagi Mahasiswa yang memiliki sifat materialisme dalam dirinya memiliki barang-barang yang 'branded' memberikan suatu nilai kemewahan serta kepuasan tersendiri. Demikian halnya dengan motivasi hedonik konsumen, untuk mengkonsumsi dan memiliki produk fashion yang diinginkan mendorong konsumen untuk melakukan pembelian baik impulsive buying maupun kecenderungan compulsive buying. Menurut Kharis, (2006) sebagian besar konsumen Indonesia memiliki karakter unplanned dan biasanya suka bertindak "last minute". Sehingga, sering kali pembelian yang dilakukan berubah dari rencana awal sebelum dan setelah memasuki Toko. Namun, akan berbeda jika konsumen berbelanja pada situs belanja Online. Penelitian ini bertujuan "Untuk Mengetahui Pengaruh Sifat Materialisme, Motivasi Hedonik terhadap Impulsive Buying dan Kecenderungan Compulsive Buying Secara Online Di Kalangan Mahasiswa Universitas Mataram".

\subsection{Kajian Teoritis}

\section{TINJAUAN PUSTAKA}

\subsubsection{Sifat Materialisme terhadap Impulsive Buying}

Konsumen dengan nilai materialisme yang tinggi meyakini bahwa benda material merupakan hal yang sangat penting bagi hidup mereka. Sifat materialisme yang ada dalam diri konsumen tersebut dapat menjadi salah satu faktor yang dapat menyebabkan timbulnya impulsive buying. Seseorang yang materialistik juga akan cenderung berbelanja untuk membeli barang yang dirasa akan menaikan derajatnya tanpa berpikir panjang dan tanpa rencana sebelumnya. Semakin tinggi sifat materialisme yang dimiliki oleh seorang konsumen, maka semakin kuat pula kecenderungan untuk tidak dapat menunda suatu pembelian (Belk,1985). Ini dikarenakan kepemilikan terhadap suatu benda menjadi 
sesuatu kebanggaan tersendiri. Materialisme yang merupakan salah satu ciri-ciri yang paling penting telah menjadi subyek dari banyak penelitian yang berdampak pada impulsive buying (Richins \& Dawson, 1992).

Hasil penelitian terdahulu yang dilakukan oleh Chandra dkk, (2014), Sari, (2014) dan Prawira, (2015), yang mengatakan bahwa sifat materialisme berpengaruh positif terhadap impulsive buying secara Online. Penelitian yang dilakukan oleh Turkilmaz at all, (2014) bahwa ciri kepribadian dapat mempengaruhi impulsive buying secara Online. Penelitian yang dilakukan oleh Podoshen dan Andrzejewski, 2012 (dalam Chandra dkk, 2014) bahwa materialisme secara positif mempengaruhi perilaku impulsive buying. Pada penelitiannya, Sun dan $\mathrm{Wu}$, (2011) telah menerapkan konsep pengaruh positif materialisme terhadap perilaku impulsive buying pada konteks Online, berdasarkan uraian tersebut maka dapat diajukan hipotesis pertama sebagai berikut;

Hipotesis 1: Sifat Materialisme berpengaruh terhadap Impulsive Buying. Semakin tinggi Sifat Materialisme maka akan semakin tinggi pula Impulsive Buying secara Online.

\subsubsection{Sifat Materialisme terhadap Compulsive Buying}

Penelitian yang dilakukan oleh Sari, (2013) menunjukkan bahwa terdapat hubungan positif signifikan sifat materialisme konsumen terhadap compulsive buying. Sifat materialisme cenderung menyebabkan individu untuk berusaha memperkaya diri dengan terus menerus menumpuk kekayaan Richins dan Dowson, 1992 (dalam Sari, 2013). Tindakan untuk mengumpulkan kekayaan atau materi merupakan sumber kebahagiaan dan kesuksesan. Tindakan untuk memperkaya diri yang dilakukan dengan frekuensi yang tinggi menyebabkan individu untuk melakukan compulsive buying. Bagi perusahaan, compulsive buying ini merupakan hal yang menguntungkan karena terjadi aktivitas pembelian secara terus menerus. Penelitian yang dilakukkan oleh Sari, (2014) menyatakan bahwa perilaku compulsive buying dapat dipengaruhi oleh sifat psikologis konsumen seperti sifat materialisme.

Penelitian yang dilakukan oleh Sari, (2014) hasil penelitian menunjukkan sifat materialisme dengan 3 dimensi berpengaruh positif terhadap compulsive buying. Naomi dan Mayasari (2009), hasil penelitian menunjukkan terdapat pengaruh sifat materialisme pada indikator happiness dan centrality. Namun, indikator Success tidak memiliki pengaruh signifikan terhadap compulsive buying. Studi Dittmar, (2005) menunjukkan bahwa sifat materialisme yang dimiliki oleh individu menyebabkan seseorang memiliki kecenderungan untuk melakukan compulsive buying. Maka dapat diajukan hipotesis kedua sebagai berikut;

Hipotesis 2 : Sifat Materialisme berpengaruh positif dan signifikan terhadap Kecenderungan Compulsive Buying. Semakin tinggi Sifat Materialisme maka akan semakin tinggi pula Kecenderungan Compulsive Buying secara Online.

\subsubsection{Motivasi Hedonik terhadap Impulsive Buying}

Menurut pendapat Overby dan Lee, (2006) setuju bahwa konsumen yang memiliki Motivasi hedonik merasa senang dan gembira dari pengalaman belanja mereka. Penelitian yang dilakukan oleh Gupta, (2013) kecenderungan perilaku belanja yang terjadi juga erat kaitannya dengan motivasi yang mendasari konsumen untuk berbelanja baik secara impulsive yang apabila dilakukan terus menerus cenderung mengarah pada suatu kebiasaan dan dapat membuat konsumen memiliki ketergantungan untuk terus menerus 
berbelanja, yang apabila hal ini berlangsung lama dapat mengarahkan pada kecenderungan compulsive buying. Veenhoven, (2003) mengatakan bahwa seseorang yang memiliki gaya hidup hedonis memandang secara positif mengenai kesenangan dan akan mengambil atau memanfaatkan kesempatan sekecil apapun untuk mencapai kesenangan yang diharapkan.

Menurut Utami, (2011) Motivasi hedonik yang berlebihan yang dimiliki seseorang dapat mengarahkan pada suatu kesenangan dan keasikan dalam berbelanja karena berbelanja dapat membangkitkan mood yang positif. Akan tetapi, apa bila hal ini dilakukan secara berlebihan justru dapat memberikan dampak yang negatif. Hal ini sesuai dengan penelitian yang dilakukan oleh Prawira, (2015) bahwa, masyarakat mengganggap kecanduan terhadap sesuatu adalah hal yang akan selalu berdampak negatif, namun bagi pemasar menganggap bahwa kecanduan masyarakat ini sebagai peluang untuk memasarkan produknya. Pada kondisi ini, menurut Lumintang, (2013) perilaku para konsumen yang memiliki sifat hedonis dapat digunakan untuk memasarkan produknya dengan memanfaatkan media Online, karena ketika seseorang berbelanja secara hedonik, maka ia tidak akan mempertimbangkan suatu manfaat dari produk tersebut sehingga kemungkinan terjadinya pembelian tanpa rencana (impulsive buying) secara Online juga akan semakin tinggi. Penelitian oleh Lina, (2015) dan Paramitha, (2015) motivasi hedonik memiliki pengaruh yang positif dan signifikan terhadap impulsive buying. Lumitang, (2013), Prawira, (2015) hasil penelitian menunjukkan motivasi hedonik berpengaruh signifikan terhadap impulsive buying secara Online. Berdasarkan uraian tersebut maka dapat diajukan hipotesis ketiga sebagai berikut;

Hipotesis 3: Motivasi Hedonik berpengaruh positif dan signifikan terhadap Impulsive Buying. Semakin tinggi Motivasi Hedonik maka semakin tinggi pula terjadinya Impulsive Buying secara Online.

\subsubsection{Motivasi Hedonik terhadap Kecenderungan Compulsive Buying}

Dowson et al, 1990 (dalam Sari, 2013) menjelaskan bahwa konsumen yang mendapat motivasi secara kuat, cenderung akan mengarah keperilaku compulsive. Ketika konsumen termotivasi melakukan pembelian suatu produk, konsumen tidak hanya menekankan utilitas suatu produk, tetapi juga pada kesenangan instrinsik atau emosi. Compulsive buying membuat konsumen melakukan pembelian berulang dan berlebihan akibat dari emosi negatif yang dialaminya. Untuk itu, penting untuk mempelajari fenomena compulsive buying karena perilaku pembelian seperti ini telah menjadi kekhawatiran bagi banyak konsumen. Dalam penelitian yang dilakukan oleh Cen dkk, (2015) menemukan terdapat kecenderungan konsumen yang melakukan compulsive buying dimana, konsumen biasanya mengkonsumsi barang atau jasa lebih banyak dibandingkan dengan konsumen lainya. Menurut Banu at all, (2013) compulsive buying dapat menyebabkan kerugian psikologis bagi konsumen itu sendiri karena menganggap kegiatan belanja sebagai aktivitas pelarian diri dari masalah emosional yang ada dan termotivasi mengkonsumsi barang atau jasa secara berlebihan akibat untuk meningkatkan harga diri dan citra sosial di lingkungannya. Perilaku pembelian seperti ini memberikan konsumen balas jasa positif dalam jangka pendek, akan tetapi pada jangka panjang terdapat konsekuensi negatif dimana konsumen memiliki kesulitan untuk mengendalikan pembelian (O'Guinn dan Faber, 1989).

Penelitian yang dilakukan oleh Felicia, (2014) menunjukkan bahwa gaya hidup hedonistik juga berkorelasi dengan kecenderungan compulsive buying. Dimana, gaya hidup hedonistik ini terjadi karena adanya sifat Hedonistik yang terdapat dalam diri konsumen 
tersebut dapat mengarahkan pada suatu kecenderungan belanja yang berlebihan. Semakin kuat motivasi hedonik yang ada dalam diri setiap konsumen maka keinginan untuk segera melakukan belanja dengan segera atau impulsive buying akan semakin besar pula dan hal ini dapat mengarah pada kecenderungan compulsive buying. Hasil penelitian Sari, (2013) menunjukkan motivasi yang dimiliki konsumen ketika berbelanja berpengaruh positif signifikan terhadap compulsive buying. Berdasarkan uraian tersebut maka dapat diajukan hipotesis keempat sebagai berikut;

Hipotesis 4: Motivasi Hedonik berpengaruh positif dan signifikan terhadap Kecenderungan Compulsive Buying. Semakin tinggi Motivasi Hedonik maka dapat mengarah pada Kecenderungan Compulsive Buying.

\subsubsection{Impulsive Buying terhadap Kecenderungan Compulsive Buying}

Impulsive buying atau biasa disebut unplanned puschase, adalah perilaku seseorang dimana seseorang tersebut tidak merencanakan sebelumnya dalam berbelanja. Kharis, (2006), sebagian konsumen Indonesia memiliki karakter unplanned dan biasanya suka bertindak "last minute". Konsumen melakukan impulsive buying tidak berpikir untuk membeli suatu produk atau merek tertentu. Mereka langsung melakukan pembelian karena ketertarikan pada produk tersebut saat itu juga. Rook dan Fisher, (1987) impulsive buying sebagai kecenderungan konsumen untuk membeli secara spontan, reflek, tiba-tiba dan otomatis. Impulsive buying dapat terjadi dimana saja dan kapan saja termasuk pada saat seseorang pemasaar menawarkan suatu produk kepada calon konsumen dan produk tersebut terkadang tidak terpikirkan dalam benak konsumen sebelumnya.

Menurut Sari, (2014) compulsive buying dapat dikategorikan sebagai salah satu pembelian yang menyimpang dan dilakukan untuk lari dari masalah serta untuk memperbaiki suasana hati. Hal ini dikarenakan bagi sebagian konsumen aktivitas belanja yang berlebihan merupakan sesuatu yang menyenangkan, dapat mengurangi stress dan sebagainya Cen dkk, (2015). Glatt dan Cook, 1987 (dalam Naomi dan Mayasari, 2009) menyatakan bahwa kecenderungan compulsive buying bisa terjadi pada setiap individu yang memiliki kondisi jiwa yang normal dan pembelian konsumen secara umum, khususnya pada individu yang memiliki daya beli yang cukup dan kecenderungan untuk membeli produk dengan frekuensi yang tinggi. Sementara itu, menurut Cen dkk, (2015) kecenderungan compulsive buying dapat terjadi pada semua orang, baik pria, wanita, tua ataupun muda.

Penelitian yang dilakukan oleh Sari, (2014) menunjukkan hubungan positif impulsive buying yang dimediasi oleh karakteristik personal terhadap compulsive buying. Artinya pengaruh impulsive buying terhadap kecenderungan compulsive buying akan semakin besar pada konsumen dengan karateristik personal yang semakin tinggi. Akan tetapi, menurut Krisjanti dan Prabowo, (2010) semakin sering seorang individu melakukan impulsive buying dalam jangka panjang akan menjadikannya sebagai pembeli dengan perilaku membeli yang berlebihan dan secara terus menerus dapat mengarah pada kecenderungan compulsive buying. Namun demikian, penelitian sebelumnya belum ada yang meneliti pengaruh langsung impulsive buying terhadap kecenderungan compulsive buying dalam konteks belanja Online. Untuk itu penelitian ini bermaksud untuk mencoba mengkaji lebih lanjut hubungan tersebut dalam konteks belanja secara Online. Sehingga dapat diajukan hipotesis kelima sebagai berikut;

Hipotesis 5: Impulsive Buying berpengaruh positif dan signifikan terhadap Kecenderungan Compulsive Buying. Semakin sering Impulsive Buying dilakukan maka dapat mengarah pada Kecenderungan Compulsive Buying. 


\subsection{Kerangka Konseptual Penelitian}

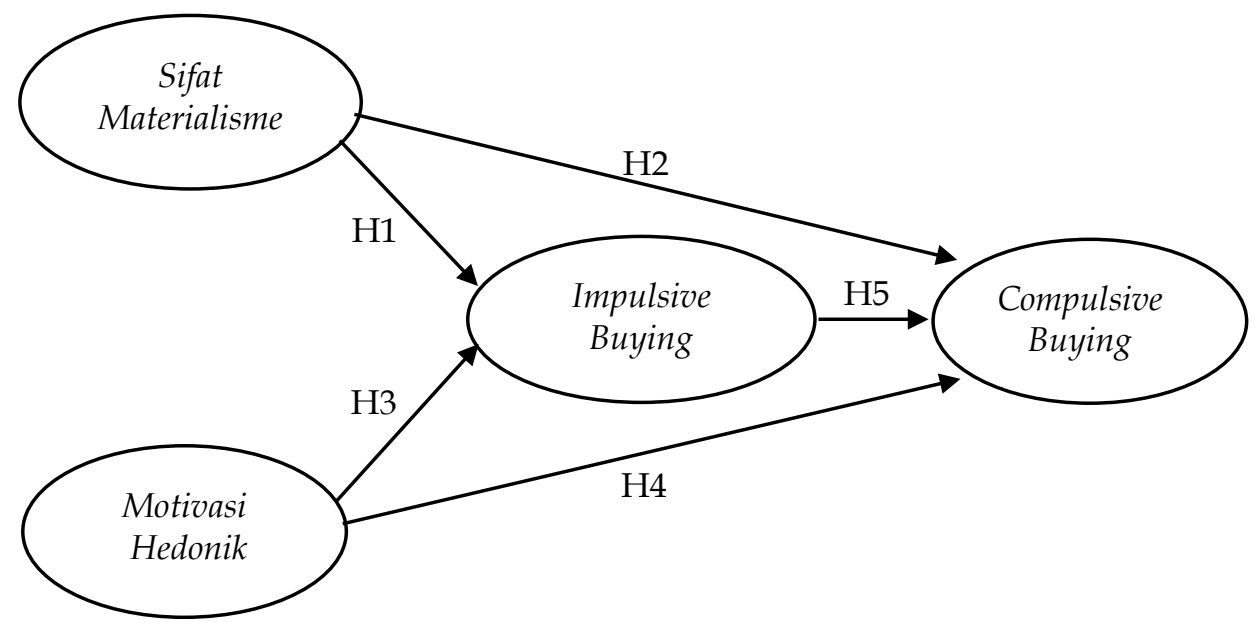

Gambar 1 : Kerangka Konseptual Penelitian

\section{METODOLOGI PENELITIAN}

Jenis penelitian menggunakan penelitian kausalitas, Populasi pada penelitian ini adalah seluruh Mahasiswa Di Kalangan Universitas Mataram yang pernah melakukan belanja secara Online dengan sampel responden sebanyak 120 responden yang terdiri dari 35 mahasiswa Diploma Tiga, Strata Satu 53 mahasiswa dan Strata Dua 32 mahasiswa. Teknik pengambilan sampel menggunakan metode Purposive Sampling. Dengan kriteria Merupakan Mahasiswa Universitas Mataram berusia 18-30 tahun, Sudah pernah melakukan belanja secara Online khususnya produk Fashion minimal 2 kali dalam 3 bulan terakhir. Alat pengumpulan data mengunakan kuesioner skala likert point 1-5 (Sangat Tidak Setuju sampai dengan Sangat Setuju). Adapun teknik analisis data menggunakan Structural Equation Modeling (SEM).

\subsubsection{Uji Validitas dan Uji Reliabilitas Penelitian}

Uji validitas dapat diketahui berdasarkan validitas konvergen. nilai validitas konvergen dapat melihat nilai dari Faktor Loading setiap variabel yang diteliti. Apabila nilainya lebih dari 0,5 maka variabel penelitian dapat dikatakan valid, Widya, (2012). Sementara menurut Ferdinand, (2014) nilai lamda $(\lambda)$ atau faktor loading sebesar lebih besar dari 0,40 . 


\section{$J M M$ UNRAM

Tabel 1 : Nilai Faktor Loading Crombahc's Alfa (CA), Composite Reliabilitas (CR) dan Average Variance Extracted (AVE) Setiap Indikator Dengan Menggunakan Uji CFA

$\begin{array}{lllll}\text { Variabel dan Indikator } & \begin{array}{c}\text { Faktor } \\ \text { Loading }\end{array} & \text { CA } & \text { CR } & \text { AVE }\end{array}$

\begin{tabular}{|c|c|c|c|c|}
\hline Sifat Materialisme & & 0,71 & 0,75 & 0,57 \\
\hline Kepemilikan barang penting dalam hidup & 0.52 & & & \\
\hline Membeli banyak barang membuat bahagia & 0.53 & & & \\
\hline Kepemilikan barang menunjukkan status & 0.74 & & & \\
\hline $\begin{array}{l}\text { Merasa resah saat tidak sanggup membeli } \\
\text { barang yang disukai }\end{array}$ & 0.53 & & & \\
\hline Membeli untuk menyenangkan diri sendiri & 0.59 & & & \\
\hline Menyukai kemewahan & 0.56 & & & \\
\hline Motivasi Hedonik & & 0,73 & 0,72 & 0,58 \\
\hline Keinginan mengikuti tren terbaru & 0.52 & & & \\
\hline Keinginan untuk memanjakan diri & 0.58 & & & \\
\hline $\begin{array}{l}\text { Adanya keinginan untuk selalu lebih dari } \\
\text { yang lain }\end{array}$ & 0.68 & & & \\
\hline Keinginan yang berlebihan & 0.54 & & & \\
\hline Adanya Keinginan untuk berbagi & 0.59 & & & \\
\hline Impulsive Buying & & 0,76 & 0,75 & 0,65 \\
\hline Spontanitas & 0.53 & & & \\
\hline Tanpa berpikir panjang & 0.89 & & & \\
\hline $\begin{array}{l}\text { Cenderung membeli banyak barang } \\
\text { meskipun tidak begitu dibutuhkan }\end{array}$ & 0.57 & & & \\
\hline Tidak mempertimbangkan konsekuensi & 0.62 & & & \\
\hline Kecenderungan Compulsive Buying & & 0,74 & 0,78 & 0,67 \\
\hline Belanja untuk merasa lebih baik & 0.62 & & & \\
\hline ingin menghabiskan uang & 0.55 & & & \\
\hline belanja tetapi tidak perduli apa yang dibeli & 0.72 & & & \\
\hline Gelisah jika tidak belanja & 0.82 & & & \\
\hline
\end{tabular}

Uji validitas yang kedua adalah dengan mengetahui validitas diskriminan. Validitas diskriminan dapat diketahui apabila rata-rata perbedaan atau Square Root (SQRT) Average Variance Extracted (AVE) dari variabel yang diteliti lebih besar dari variabel latennya (Forner dan Larcker, 1981 dalam Widya, 2012). Nilai AVE digunakan untuk menguji akar kuadrat dari setiap AVE apakah korelasi lebih besar dari setiap konstruk laten. Jika SQRT AVE $>$ korelasi antar konstruk maka dapat disimpulkan bahwa validitas diskriminan dapat diterima dengan baik (Latan, 2013).

Tabel 2 : Squared Korelasi Antar Konstruk

\begin{tabular}{lcccc}
\hline \multicolumn{1}{c}{ Variabel } & $\begin{array}{c}\text { Sifat } \\
\text { Materialisme }\end{array}$ & $\begin{array}{c}\text { Motivasi } \\
\text { Hedonik }\end{array}$ & $\begin{array}{c}\text { Impulsive } \\
\text { Buying }\end{array}$ & $\begin{array}{c}\text { Kecenderungan } \\
\text { Compulsive } \\
\text { Buying }\end{array}$ \\
\hline Sifat Materialisme & $\mathbf{0 , 7 6}$ & & & \\
\hline Motivasi Hedonik & 0,17 & $\mathbf{0 , 7 6}$ & & \\
\hline Impulsive Buying & 0,16 & 0,06 & $\mathbf{0 , 8 1}$ & $\mathbf{0 , 8 2}$ \\
\hline $\begin{array}{l}\text { Kecenderungan } \\
\text { Compulsive Buying }\end{array}$ & 0,39 & 0,33 & 0,20 & \\
\hline Garis diagonal merupakan SQRT AVE & & &
\end{tabular}


Selanjutnya dilakukkan Uji reliabilitas. Uji reliabilitas dalam penelitian ini dengan melihat nilai Crombach's Alpha yang menunjukkan seberapa baik butir-butir pertanyaan berkorelasi secara positif satu sama lain. Nilai Crombach's Alpha yang dapat diterima adalah 0,6 atau lebih Zikmund, 2003 (dalam Widya, 2012). Penelitian lain menekankan bahwa nilai Alpha (a) minimum 0,7 lebih diinginkan Hair et el, 1995. Uji reliabilitas yang kedua adalah menghitung nilai Composite Reliabilitas dari masing-masing variabel. Menurut Hair et all, 1995 (dalam Ferdinand, 2014) Composite Reliability yang dapat diterima adalah $\geq 0,70$. Uji reliabilitas yang ketiga adalah menghitung Nilai Average Variance Extracted (AVE) yang tinggi menunjukkan bahwa indikator-indikator tersebut telah mewakili secara baik konstruk laten yang dikembangkan Hair et all, 1995 (dalam Ferdinand, 2014). Nilai Average Variance Extracted (AVE) minimum untuk menyatakan bahwa keandalan telah tercapai adalah sebesar 0,50 (Wijayanto, 2008). Nilai Average Variance Extracted (AVE) dibawah 0,50 menunjukkan bahwa indikator memiliki rata-rata tingkat error yang lebih tinggi.

\section{HASIL DAN PEMBAHASAN}

\subsection{Profil Responden}

Responden dalam penelitian ini adalah sebanyak 120 responden (Mahasiswa yang pernah melakukan belanja produk Fashion secara Online minimal 2 kali dalam 3 bulan terakhir. Sebanyak 120 kuesioner yang disebar dengan menggunakan teknik wawancara terbuka dan tertutup. Adapun profil responden penelitian terdiri dari Usia, Jenis Kelamin, Tingkat Pendidikan dan Pendapatan dapat dilihat pada Tabel 4.1.

Berdasarkan Tabel 3 menunjukkan hasil yang beragam dimana, profil responden penelitian berdasarkan usia didominasi responden dengan rentang usia 20-25 tahun sebanyak 47,5 persen Mahasiswa, selanjutnya rentang usia<20 tahun sebanyak 33.3 persen, sementara responden dengan rentang usia 26-30 tahun sebanyak 19,2 persen. Hal ini menunjukkan bahwa responden dengan tingkat usia $<20$ tahun hingga 20-25 tahun relatif cepat tergoda serta rasa ingin mencoba suatu hal yang baru cenderung lebih tinggi dibandingkan dengan responden diatas kategori usia tersebut. Hal inipun senada dengan hasil survei oleh APJI bahwa fenomena tingkat pengguna internet di Indonesia lebih didominasi oleh kalangan remaja usia 18-25 tahun. Ini dapat menjadi salah satu faktor penyebab tingginya belanja Online pada kategori usia tersebut. Disisi yang lain kalangan remaja juga apabila berkaitan dengan penampilan juga menjadikan suatu hal yang sangat penting dan selalu ingin terlihat lebih fashionable dengan produk-produk yang upto-date pada situs belanja Online. 
Tabel 3; Profil Responden Penelitian terdiri dari Usia, Jenis Kelamin, Tingkat Pendidikan dan Pendapatan

\begin{tabular}{|c|c|c|c|}
\hline & Profil Responden & $\begin{array}{l}\text { Jumlah } \\
\text { (Orang) }\end{array}$ & $\begin{array}{c}\text { Persentase } \\
(\%)\end{array}$ \\
\hline \multirow{4}{*}{ Usia (Tahun) } & $<20$ Tahun & 40 & 33.3 \\
\hline & 20-25 Tahun & 57 & 47.5 \\
\hline & 26-30 Tahun & 23 & 19.2 \\
\hline & Total & 120 & 100 \\
\hline \multirow{3}{*}{ Jenis Kelamin } & Laki-laki & 37 & 30.8 \\
\hline & Wanita & 83 & 69.2 \\
\hline & Total & 120 & 100 \\
\hline \multirow{4}{*}{$\begin{array}{l}\text { Tingkat } \\
\text { Pendidikan }\end{array}$} & Diploma Tiga (D3) & 35 & 29.2 \\
\hline & Strata Satu (S1) & 53 & 44.2 \\
\hline & Strata Dua (S2) & 32 & 26.7 \\
\hline & Total & 120 & 100 \\
\hline \multirow{5}{*}{$\begin{array}{l}\text { Pendapatan } \\
\text { Perbulan }\end{array}$} & $<\operatorname{Rp} 1.000 .000,-$ & 74 & 61.7 \\
\hline & Rp 1 Juta- Rp 2.500.000,- & 32 & 26.7 \\
\hline & Rp 2.500.000-Rp 3.500.000,- & 9 & 7.5 \\
\hline & $>$ Rp 3.500.000,- & 5 & 4.2 \\
\hline & Total & 120 & 100 \\
\hline
\end{tabular}

Berdasarkan Tabel 3 di atas juga diketahui bahwa responden berdasarkan jenis kelamin lebih didominasi oleh responden kalangan Wanita sebanyak 69.2 persen dibandingkan responden kalangan Laki-laki hanya sebesar 38 persen. Hal ini dapat dipahami bahwa, kalangan remaja wanita begitu identik dengan produk Fashion, bagi kalangan Wanita berbicara Fashion menjadi suatu topik pembicaraan yang tiada habisnya. Sementara, berdasarkan Tabel 3 juga dapat diketahui bahwa tingkat pendidikan responden jenjanng Strata Satu (S1) lebih besar dibandingkan dengan responden jenjang pendidikan Diploma Tiga (D3) dan Strata Dua (S2). Demikian halnya dengan tingkat pendapatan responden, berdasarkan tabel yang sama menunjukkan bahwa rata-rata responden dengan tingkat pendapatan $<$ Rp 1.000.000,-perbulan lebih dominan. Hal ini dikarenakan rata-rata mahasiswa Diploma Tiga (D3) dan Strata Satu (S1) berdasarkan hasil wawancara singkat oleh peneliti, kebanyakan responden mengaku masih mengandalkan uang belanja dari orang tua mereka. Namun, beberapa diantara mereka mengaku ada juga yang sudah bekerja. Sementara responden dengan tingkat pendidikan Strata Dua (S2) sebagian besar responden mengaku berbelanja Online dengan menggunakan sumber pendapatan sendiri dan ada juga yang berpendapatan $<\mathrm{Rp}$ 1.000.000,-perbulan namun tetap melakukan belanja secara Online dengan berbagai alasan diantaranya karena tertarik dengan adanya discount, ingin mengikuti tren, adanya kebutuhan serta tuntutan gaya hidup.

\subsection{Hasil Analisis Data dan Pembahasan}

Berikut ini merupakan hasil uji kelayakan model evaluasi atau model akhir yang telah dilakukan. Berdasarkan Gambar 2 menunjukan bahwa hasil uji kelayakan keseluruhan model dapat dikatakan fit. Hasil pengujian kelayakan model secara keseluruhan dapat dikatakan baik dan memenuhi kriteria Goodness-Off-Fit atau memenuhi syarat Cut-Off-Value yang ditentukan. Nilai GFI 0,868 dan AGFI 0,826 dengan RMSEA 0,041 pada Probabilitas 0,50. Sehingga dapat disimpulkan bahwa konstruk-konstruk 
yang digunakan dalam penelitian ini sudah mencerminkan variabel laten endogen serta variabel laten eksogen yang di analisis.



Gambar 2: Hasil Uji Kelayakan Model

Secara umum, pengujian hipotesis ini dilakukan dengan melihat nilai critical ratio (c.r) dan nilai signifikan $p$ sebagai hasil dari pengolahan data yang dibandingkan dengan batasan statistik yang disyaratkan. Nilai critical ratio yang dipersyaratkan adalah diatas 1,96 dan nilai probabilitas yang disyaratkan adalah di bawah 0,05. Jika hasil dari pengolahan data memenuhi persyaratan tersebut, maka hipotesis dalam penelitian yang diajukan dinyatakan dapat diterima. Masing-masing pengujian hipotesis dalam penelitian ini akan dibahas sebagai berikut:

Tabel 4: Hasil Test Hipotesis Penelitian

\begin{tabular}{|c|c|c|c|c|c|c|c|}
\hline Hipotesis & Jalur & $\beta$ & E & c.r & $P$ & Label & Kesimpulan \\
\hline $\begin{array}{c}\text { Hipotesis } \\
1\end{array}$ & $\begin{array}{l}\text { Sifat Materialisme } \rightarrow \\
\text { Impulsive Buying }\end{array}$ & 0,35 & ,330 & 2,257 & ,024 & Signifikan & Mendukung \\
\hline $\begin{array}{l}\text { Hipotesis } \\
2\end{array}$ & $\begin{array}{l}\text { Sifat Materialisme } \rightarrow \\
\text { Compulsive Buying }\end{array}$ & 0,32 & ,304 & 2,311 & ,021 & Sion & $\mathrm{hg}$ \\
\hline $\begin{array}{c}\text { Hipotesis } \\
3\end{array}$ & $\begin{array}{l}\text { Motivasi Hedonik } \rightarrow \\
\text { Impulsive Buying }\end{array}$ & 0,04 & ,047 & 258 & ,796 & $\begin{array}{c}\text { Tidak } \\
\text { Signifikan }\end{array}$ & $\begin{array}{c}\text { Tidak } \\
\text { Mendukung }\end{array}$ \\
\hline $\begin{array}{l}\text { Hipotesis } \\
4\end{array}$ & $\begin{array}{l}\text { Motivasi Hedo } \\
\text { Compulsive Bu }\end{array}$ & 0,37 & 461 & 2,523 & ,012 & ikan &  \\
\hline $\begin{array}{l}\text { Hipotesis } \\
5\end{array}$ & $\begin{array}{l}\text { Impulsive Buying } \rightarrow \\
\text { Compulsive Buying }\end{array}$ & 0,24 & 243 & 2,173 & ,030 & ignifikan & ung \\
\hline
\end{tabular}

Keterangan; E (estimasi), c.r (critical ratio), p (probability)

Hipotesis pertama pada penelitian ini adalah sifat materialisme terhadap impulsive buying. Sehingga semakin tinggi sifat materialisme, maka semakin tinggi terjadinya impulsive buying. Berdasarkan hasil pengolahan data diketahui bahwa nilai C.R (Critical 
Ratio) untuk pengaruh antara variabel sifat materialisme terhadap impulsive buying seperti terlihat pada Tabel 4 adalah sebesar 2,257 dengan nilai signifikan $p$ sebesar 0,024. Kedua nilai ini menunjukkan hasil yang memenuhi syarat, yaitu diatas 1,96 untuk C.R (Critical Ratio) dan dibawah 0.05 untuk nilai probability. Sementara nilai koofisien jalur $\beta$ sebesar 0,35 . Ini menunjukkan bahwa sifat materialisme memiliki kontribusi serta pengaruh yang positif terjadinya impulsive buying. Sehingga dapat disimpulkan bahwa hipotesis 1 pada penelitian ini dapat didukung atau diterima.

Hasil penelitian ini konsisten dengan hasil penelitian yang dilakukkan oleh Chandra dkk, (2014), Sari, (2014) dan Prawira, (2016) yang menunjukkan bahwa sifat materialisme berpengaruh positif dan signifikan terhadap impusive buying yang dilakukkan oleh konsumen. Hasil penelitian ini juga konsisten dengan kajian empiris yang dilakukkan oleh Tulkimaz. at all, (2014) dimana faktor psikologis konsumen seperti sifat materialisme dapat memicu seseorang melakukkan impulsive buying secara Online. Bagi mahasiswa yang memiliki sifat materialisme yang tinggi dalam dirinya tentunya kepemilikan suatu barang seperti salah satunya produk fashion adalah suatu hal yang penting dalam hidupnya. Tidak bisa dipungkiri, kepemilikan sesuatu materi menentukan eksistensi seseorang dalam lingkungan atau komunitasnya. Sehingga ketika konsumen menganggap suatu barang tertentu penting dalam hidupnya sebagai ukuran kesuksesan dan kebahagiaan, konsumen yang materialisme tidak akan menunda untuk melakukkan impulsive buying.

Hal ini terlihat dari indikator "kepemilikan barang penting dalam hidup" dan "membeli banyak barang membuat bahagia" memicu konsumen melakukan pembelian secara "spontan" maupun membeli "tanpa berpikir panjang". Artinya, ketika konsumen menganggap penting kepemilikan suatu barang maka konsumen tersebut tidak akan berpikir panjang untuk segera melakukan pembelian. Selain itu, ketika "kepemilikan barang penting dalam hidup", konsumen akan "cenderung membeli banyak barang meskipun tidak begitu dibutuhkan" serta "tidak mempertimbangkan konsekuensi". Demikian halnya dengan indikator "membeli banyak barang membuat bahagia". Artinya, ketika barang yang dimiliki begitu penting dalam hidup dan memberikan kebahagiaan, maka konsumen tersebut tidak akan banyak pertimbangan dalam berbelanja sehingga pembelian impulsive secara Online terjadi.

Hipotesis kedua yakni sifat materialisme terhadap kecenderungan compulsive buying, sehingga semakin tinggi sifat materialisme, maka semakin tinggi pula terjadinya kecenderungan compulsive buying. Dari hasil pengolahan data diperoleh nilai c.r (critical ratio) pengaruh antara sifat materialisme terhadap kecenderungan compulsive buying adalah Ssebesar 2,311 diatas 1,96 dengan nilai signifikan $p$ sebesar 0,021; pada tingkat signifikan $p<0,05$ sementara nilai kofisien jalur $\beta$ sebesar 0,32 menunjukkan sifat materialisme juga mempunyai pengaruh yang positif dan signifikan terhadap kecenderungan compulsive buying. Sehingga dapat di simpulkan bahwa hipotesis ke 2 didukung atau diterima. Hasil ini sesuai dengan kajian yang dilakukkan oleh Ditmar, (2005) bahwa sifat materialisme yang ada dalam diri setiap konsumen menjadi salah satu faktor yang dapat menyebabkan timbulnya kecenderungan compulsive buying. Hasil penelitian ini juga konsisten dengan penelitian yang dilakukkan oleh Sari, (2013) dan Sari, (2014) dengan menggunakan indikator yang berbeda dengan penelitian ini, dimana hasil penelitian menunjukkan bahwa sifat materialisme berpengaruh positif signifikan terhadap kecenderungan compulsive buying.

Menurut Naomi dan Mayasari, (2008) nilai materialisme yang kuat menyebabkan individu merasa tidak berarti bila tidak memiliki suatu barang. Ketika konsumen 
menganggap "kepemilikan barang penting dalam hidup" konsumen atau dalam hal ini adalah kalangan mahasiswa maka untuk mendapatkan barang yang di inginkan, konsumen tersebut tidak akan ragu untuk "menghabiskan uang" belanjanya baik sebagian atau seluruhnya. Sebaliknya apabila barang tersebut tidak sanggup di beli maka konsumen tersebut akan "merasa gelisah" dan akan berusaha mengatasi masalah yang dihadapi dengan berbagai cara misalnya seperti salah satunya dengan berhutang. Karena bagi konsumen yang compulsive belanja dapat memperbaiki suasan hati menjadi lebih baik dan merupakan suatu bentuk trait kepribadian. Pembelian compulsive memiliki dampak jangka panjang dan dampak jangka pendek. Menurut Gwin et al,.(2005) dampak jangka panjang yaitu dapat memicu terjadinya kebangkrutan, hutang yang menumpuk dan lain-lain. Sementara dampak jangka pendek menurut (Soliha, 2012) yaitu konsumen dapat langsung merasakan kepuasan dan kesenangan ketika proses belanja berlangsung. Konsumen usia remaja seperti halnya Mahasiswa ternyata sudah mengadopsi secara kuat nilai materialisme berupa kepemilikan suatu barang. Nilai ini muncul karena adanya pengaruh sosial media, televisi, lingkungan perteman, dan bahkan dari lingkunga keluarga yang mulai menanamkan bahwa dengan memiliki sesuatu menjadikan seseorang menjadi berarti dan dihargai. Remaja seperti Mahasiswa menunjukkan materialisme dengan kepemilikan produk-produk yang bisa dilihat oleh temannya salah satunya yang berkaitan dengan produk Fashion.

Nilai materialisme juga tumbuh karena pengaruh keinginan agar diterima dalam kelompok tertentu dengan baik. Tidak bisa dipungkiri, sebagian individu merasa bahwa teman membawa arti penting dalam kehidupannya. Ketika konsumen menganggap kepemilikan adalah suatu yang berarti atau penting, maka konsumen tersebut tentunya akan terus melakukan pembelian sehingga menjadikan belanja sebagai suatu rutinitas serta gaya hidup yang menyenangkan sehingga secara tidak langsung konsumen tersebut akan menghabiskan uangnya untuk memenuhi hastrat belanjanya tersebut dan hal ini dapat mengarah pada kecenderungan compulsive buying. Hal ini sesuai dengan pendapat dari (Cen, 2015, Dita Sari, 2014) bahwa pembelian compulsive dapat terjadi pada perilaku belanja konsumen secara umum baik pria, wanita, tua ataupun usia muda.

Hipotesis ketiga yaitu motivasi hedonik berpengaruh terhadap impulsive buying. Dari hasil olah data ditemukan bahwa dari Tabel 4.11 menunjukkan nilai c.r pengaruh antara motivasi hedonik terhadap impulsive buying adalah nilai probability 0,796; $p>0,05$ sementara nilai c.r diperoleh $0,258<1,96$ dengan nilai koofisien sebesar $\beta 0,04$. Ini menunjukkan bahwa motivasi hedonik tidak mempunyai pengaruh yang signifikan terhadap terjadinya impulsive buying. Walaupun hubungan yang terbentuk positif tetapi tidak terlalu signifikan. Sehingga dapat disimpulkan bahwa hipotesis ketiga tidak dapat diterima atau tidak didukung. Hal ini berbeda dengan hasil penelitian yang dilakukkan oleh Lina, (2015), Lumintang, (2013), Prawira, (2015) dan Paramitha, (2015) menunjukkan motivasi hedonik berpengaruh positif signifikan terhadap impulsive buying. Hal ini merupakan suatu hal yang wajar, menurut (Lizamari dkk, 2014) seseorang yang memiliki nilai hedonik yang tinggi terkadang memiliki banyak pertimbangan saat akan melakukkan pembelian seperti salah satunya adalah pertimbangan faktor ekonomi. Hal ini terihat dari beberapa indikator seperti "keinginan mengikuti tren terbaru" dan "keinginan untuk memanjakan diri" walaupun kedua indikator tersebut, berada pada kategori tinggi tetapi tidak lantas membuat Mahasiswa menjadi pembeli yang spontan, ataupun menjadi pembeli yang "tanpa berpikir panjang" saat membeli produk Fashion secara Online.

Hal ini dapat dipahami bahwa, berdasarkan hasil wawancara dengan beberapan responden yang dilakukkan oleh peneliti, mayoritas responden memang memiliki 
motivasi hedonik yang tinggi terkait keinginan membeli produk Fashion secara Online, tetapi tidak lantas menjadi pembeli yang impulsive. Hal ini dapat dipahami bahwa mayoritas $61,7 \%$ Mahasiswa yang menjadi responden penelitian memiliki tingkat pendapatan kurang dari Rp 1.000.000,- dan masih belum mandiri dari segi pendapatan. Selain itu, dari hasil pertanyaan terbuka yang terdapat dalam kuesioner serta hasil interview langsung dengan beberapa responden mengatakan bahwa motivasi mereka berbelanja salah satunya adalah akan berbelanja produk Fashion ketika butuh atau faktor kebutuhan. Ketika seorang konsumen berbelanja Online didorong adanya faktor pemenuhan kebutuhan sementara biaya yang dimiliki tidak mendukung, maka konsumen tersebut akan cenderung lebih terencana dalam berbelanja sehingga pembelian impulsive buying relatif sulit terjadi. Artinya ketika konsumen berbelanja produk Fashion secara Online lebih terdorong karena motiv utilitarian atau manfaat utama dari produk yang akan dikonsumsi, maka konsumen tersebut cenderung lebih rasional dalam membelanjakan uangnya. Berkaitan dengan hal tersebut, maka motif hedonik atau motif emosional yang berupa kesenangan yang bersifat jangka pendek seperti kebanggaan, kesenangan, kepuasan, gengsi, cenderung di kesampingkan untuk sementara waktu. Namun demikian, sering kali kedua motiv tersebut berfungsi secara bersamaan dalam proses pembelian yang dilakukan oleh konsumen (Setiadi, 2003).

Untuk hipotesis keempat, motivasi hedonik terhadap kecenderungan compulsive buying, semakin tinggi motivasi hedonik maka akan semakin tinggi pula kecenderungan compulsive buying terjadi. Hasil ini dibuktikan dengan nilai koofisien jalur $\beta 0,37$ pada tingkat signifikan probability 0,012; $p<0,05$ dengan c.r diatas 1,96 yaitu sebesar 2,523. Ini menunjukkan bahwa motivasi hedonik mempunyai pengaruh yang positif dan signifikan terhadap kecenderungan compulsive buying. Sehingga dapat disimpulkan bahwa hipotesis ke 4 dapat diterima karena memenuhi syarat yang telah ditentukan. Menurut Dowson et all, 1990 (dalam Sari, 2013) bahwa konsumen yang memiliki motivasi belanja yang tinggi cenderung mengarah pada perilaku pembelian compulsive. Hasil penelitian ini juga konsisten dengan penelitian yang dilakukkan oleh Felicia, (2014) bahwa gaya hidup hedonistik berkorelasi positif terhadap kecenderungan compulsive buying. Penelitian oleh Sari, (2013) menunjukkan bahwa motivasi hedonik berpengaruh positif dan signifikan terhadap compulsive buying. Hal ini dikarenakan Mahasiswa di kalangan Universitas Mataram cenderung memiliki motivasi hedonik yang tinggi ketika berbelanja produk Fashion secara Online. Konsumen ketika berbelanja produk biasanya hanya didasarkan pada keinginan untuk memenuhi aspek utilitas atau kegunaan utama suatu produk, tetapi juga menginginkan sesuatu diluar aspek utilitas tersebut yaitu kebutuhan untuk mendapatkan rasa senang, keinginan untuk menghabiskan uang karena hobi belanja, untuk memperbaiki suasan hati yang negatif serta ingin menjadi lebih dari yang lain dalam lingkungan komunitasnya, sehinga konsumen yang compulsive selalu merasa tidak tercukupi dengan apa yang dimiliki. Menurut Cen dkk, (2015) menemukan bahwa terdapat kecenderungan konsumen yang melalukan compulsive buying dimana konsumen tersebut biasanya mengkonsumsi barang atau jasa lebih banyak dibandingkan dengan konsumen lainnya.

Menurut Moven, (2002) bahwa compulsive buying sebagai "respons terhadap dorongan yag tidak terkendali atau keinginan untuk memperoleh, menggunakan atau mengalami suatu perasaan, substansi atau kegiatan yang menuntuk individu untuk secara berulang kali terlibat dalam perilaku yang akhirnya merugikan individu atau individu lain". Sementara menurut Naomi dan Mayasari, (2009) konsumen modern mengkonsumsi demi kepentingan "hasrat" hedonis terdalamnya yang nyata-nyata tak 
pernah terbatas. Sehingga konsumen yang hedonis memiliki dorongan yang kuat dan berusaha untuk mendapatkan kepuasan, kenikmatan, prestige, dan mengejar pengakuan diri sebagai manusia modern. Sehingga muncul keinginan untuk memenuhi kebutuhan tersebut secara terus-menerus. Pembelian yang terus-menerus inilah yang merupakan bentuk pembelian yang dapat mengarah pada kecenderungan compulsive buying.

Hal ini dapat tergambar dari beberapa indikator penelitian seperti "mengikuti tren terbaru" ketika seorang mahasiswa mampu mendapatkan produk Fashion keluaran terbaru maka konsumen tersebut akan merasa lebih baik serta keinginan untuk menghabiskan uang untuk memenuhi keinginan tersebut akan terjadi, sehingga konsumen tersebut akan cenderung membeli barang tetapi tidak perduli apa yang dibeli. Karena bagi mereka yang hedonik kesenangan, kepuasan, gensi, prestige serta faktor subjektif lainnya jauh lebih penting. Sebaliknya apabila produk Fashion yang sedang menjadi tren tersebut tidak sanggup dibeli maka mereka yang compulsive akan merasa gelisah jika tidak berbelanja. Karena bagi konsumen yang compulsive belanja adalah suatu bentuk untuk memperbaiki suasana hati yang negatif.

Terakhir adalah uji hipotesis kelima, impulsive buying terhadap kecenderungan compulsive buying, semakin tinggi impulsive buying terjadi maka dapat menggarah pada kecenderungan compulsive buying. Hasil olah data diperoleh nilai c.r sebesar 2,173 jauh diatas 1,96, nilai koefisien jalur $\beta ; 0,24$ dengan nilai signifikan probability 0,03; $p<0,05$ sehingga dapat ditarik kesimpulan bahwa hipotesis ke 5 dalam penelitian ini dapat diterima. Hasil ini didukung oleh pendapat yang dikemukkan oleh Krisjanti dan Prabowo, (2010) yang menyatakan bahwa semakin sering seseorang individu melakukan impulsive buying dalam jangka panjang akan menjadikannya sebagai pembeli dengan perilaku membeli yang berlebihan dan secara terus menerus dapat mengarah pada kecenderungan compulsive buying.

Masyarakat Indonesia pada umunya sangat suka sekali dalam berbelanja dan dikenal sebagai masyarakat dengan tingkat konsumtif yang relatif tinggi di Asia Tenggara (Utami, 2011). Hal ini sedikit banyak berpengaruh pada pola belanja serta pola konsumsi yang dilakukan oleh konsumen dalam hal ini adalah impulsive buying maupun kecenderungan compulsive buying. Ketika konsumen berbelanja secara impulsive, konsumen tersebut tidak akan mempertimbangkan manfaat dari produk yang dibeli karena pembelian yang dilakukkan secara leflek, tiba-tiba, spontan dan tanpa ada niatan belanja sebelumnya yang biasanya mencari kesenangan serta kepuasan sesaat. Hal ini bisa jadi disebabkan karena berbagai hal seperti adanya discount atau adanya faktor pemenuhan kebutuhan. Sementara konsumen yang compulsive buying ketika berbelanja lebih kepada kegiatan belanjanya seperti untuk memperbaiki suasan hati menjadi lebih baik, ingin menghabiskan uang sehingga konsumen yang compulsive cenderung membeli sesuatu tetapi tidak perduli apa yang dibeli. Ini dikarenakan konsumen yang compulsive lebih kepada aktivitas belanjanya dari pada keinginan untuk memiliki produknya. Sebaliknya konsumen yang compulsive akan merasa gelisah jika tidak berbelanja.

Bagi beberapa peneliti perilaku compulsive buying merupakan suatu trait kepribadian yang memberikan kesenangan dalam jangka pendek, akan tetapi dalam jangka panjang perilaku compulsive buying menjadi perilaku pembelian yang cenderung memberikan dampak yang negatif bagi konsumen dan menjadi kekhawatiran bagi banyak pihak. Dimana konsumen yang compulsive akan cenderung pada pemborosan serta berlebihan dalam berbelanja dan susah untuk mengendalikan hastrat belanja yang dimiliki. Namun bagi pemasar perilaku compulsive buying konsumen merupakan suatu peluang dalam memasarkan produk. Hasil pembagian kuesioner yang dilakukan peneliti 
menunjukkan bahwa Di Kalangan Mahasiswa Universitas Mataram rata-rata berada pada kategori cenderung compulsive buying ketika berbelanja produk Fashion secara Online. Hal ini dapat dipahami bahwa, dari hasil wawancara dengan beberapa responden mengatakan aktivitas belanja dilakukan salah satunya untuk menghilangkan kejenuhan, hal ini merupakan sesuatu hal wajar menginggat kalangan mahasiwa sering kali dihadapkan pada rutinitas kegiatan yang relatif kompleks. Sehingga sering kali menurut Faber dan O'Guinn, 1989 (dalam Felicia, 2014) bahwa kecenderungan individu melakukan pembelian berulang sebagai akibat adanya perasaan yang kurang menyenangkan atau perasaan negatif. Untuk itu, menurut Soliha, (2002) dengan berbelanja konsumen tersebut mendapatkan menghilangkan kejenuhan tersebut.

\section{KESIMPULAN DAN SARAN}

\subsection{Kesimpulan}

Terdapat pengaruh dan hubungan yang positif dan signifikan antara variabel Sifat Materialisme terhadap Impulsive Buying. Demikian halnya dengan variabel Sifat Materialisme terhadap Kecenderungan Compulsive Buying berpengaruh positif dan signifikan. Sementara Motivasi Hedonik berpengaruh tidak signifikan terhadap Impulsive Buying. Terdapat hubungan positif dan signifikan Motivasi Hedonik terhadap Kecenderungan Compulsive Buying dan merupakan variabel yang memiliki nilai signifikan yang paling tinggi. Terdapat pengaruh yang positif dan signifikan Impulsive Buying terhadap Kecenderungan Compulsive Buying. Dari hasil analisis data juga ditemukan adanya korelasi yang sangat kuat antara variabel sifat materialime terhadap motivasi hedonik walaupun dalam penelitian ini peneliti tidak mengkaji adanya hubungan kedua variabel tersebut. Hasil dari penelitian menunjukkan bahwa impulsive buying maupun kecenderungan compulsive buying dapat juga terjadi apabila dilakukan secara Online. Hasil penelitian ini juga membuktikan bahwa faktor psikologis konsumen seperti sifat materialisme dan motivasi hedonik dapat menjadi penyebab terjadinya impulsive buying maupun kecenderungan compulsive buying, akan tetapi variabel motivasi hedonik tidak memberikan pengaruh yang signifikan terhadap impulsive buying. Hal ini menunjukkan bahwa walaupun Kalangan Mahasiswa Universitas Mataram memiliki motivasi hedonik yang tinggi tetapi tidak lantas menjadikannya sebagai pembeli yang impulsive akan tetapi justru mengarah pada kecenderungan compulsive buying. Ini merupakan suatu hal yang wajar menginggat pembelian yang dilakukan secara Online. Dimana konsumen cenderung lebih berhati-hati dan terencana dalam melakukan pembelian.

Hasil Temuan ini dukung oleh Cuneyt dan Gautam, (2004) bahwa psikologis konsumen menjadi faktor utama yang mendorong konsumen untuk melakukan belanja secara Online. Tulkimaz, at all, (2014) Turki, menyatakan ciri kepribadian atau psikologis konsumen seperti sifat materialisme dapat memicu seseorang melakukan impulsive buying secara Online. Namun berbeda dengan kajian yang dilakukan Burns dan Dick, (2001) bahwa faktor lingkungan seperti pengetahuan internet, pendapatan, dan tingkat pendidikan merupakan prediktor yang paling kuat yang dapat mempengaruhi pembelian konsumen secara Online. Temuan inipun membuktikan bahwa impulsive buying yang dilakukan oleh konsumen biasanya dilakukan secara Off-line akan tetapi dapat juga terjadi ketika konsumen berbelanja secara Online, hal ini menjawab kajian yang dilakukan oleh Jefrey dan Hodge, (2007) bahwa impulsive buying selama ini hanya difokuskan pada gerai Toko dan pusat perbelanjaan. Hasil penelitian inipun membuktikan bahwa kecenderungan compulsive buying juga dapat terjadi di negara-negara berkembang dan 
dilakukan dalam konteks belanja secara Online, menginggat penelitian terkait kecenderungan compulsive buying selama ini lebih banyak di fokuskan pada negaranegara maju. Namun, masih sangat sedikit yang mencoba meneliti kecenderungan compulsive buying di negara berkembang seperti Indonesia terlebih dalam konteks belanja secara Online dengan mengambil sampel responden Di Kalangan Mahasiswa Universitas Mataram adalah yang pertama kali di lakukan.

\subsection{Saran}

Bagi pelaku bisnis Online di Indonesia hendaknya terus meningkatkan perilaku impulsive buying maupun kecenderungan compulsive buying konsumen melalui strategi promosi penjualan yang efektif yang dapat memicu serta mempengaruhi psikologis konsumen untuk terus melakukan pembelian impulsive maupun compulsive, karena ketika konsumen berbelanja secara impulsive maupun compulsive konsumen tersebut kurang menghiraukan manfaat atau utilitas utama dari suatu produk yang dibeli sebaliknya lebih mementingkan aspek kesenangan, hiburan, kepuasan serta ingin menyalurkan kebiasaan belanjanya dan hal ini sangat menguntungkan bagi pemasar.

Bagi Kalangan Mahasiswa, hendaknya untuk mengontrol sifat materialisme serta motivasi hedonik yang ada dalam dirinya agar tidak terlalu berlebihan ditenggah tuntutan gaya hidup modern, menginggat mayoritas responden kalangan mahasiswa masih belum mandiri dari segi pendapatan, sebaiknya agar lebih bijak dalam membelanjakan uangnya agar tidak mudah untuk tergoda apabila ada penawaran yang menarik dari pemasar yang dapat memicu terjadinya pembelian yang impulsive yang pada akhirnya apabila dilakukan terus menerus dapat mengarah pada kecenderungan compulsive buying. Bagi konsumen dalam hal ini kecenderungan compulsive buying dapat memberikan berbagai dampak baik jangka pendek maupun jangka panjang bagi pelakunya dan perilaku belanja comupulsive buying akhir-akhir ini menjadi perhatian bagi banyak kalangan peneliti.

Bagi penelitian selanjutnya, untuk mengkaji kembali penelitian terkait variabelvariabel dalam penelitian ini dengan belanja produk fashion secara Online namun akan menarik apabila ditambahkan variabel-variabel lain diluar dari variabel yang ada dalam penelitian ini. Hal ini dikarenakan perkembangan jumlah penguna internet yang ditunjang oleh kemajuan teknologi yang terus meningkat mengakibatkan perubahan pada gaya hidup konsumen baik dari segi psikologis serta pola perilaku belanja konsumen. selain itu akan lebih menarik bagi penelitian selanjutnya untuk mencoba membandingkan variabel psikologis maupun perilaku belanja konsumen dilakukan secara Online maupun secara Offline.

\subsubsection{Keterbatasan Penelitian}

Dalam penelitian ini terdapat beberapa keterbatasan yaitu: Penelitian ini hanya sebatas pada variabel Sifat Materialisme dan Motivasi Hedonik terhadap Impulsive Buying dan Kecenderungan Compulsive Buying. Kedepan diharapkan agar dapat memperluas cakupan penelitian terkait Impulsive Buying maupun Kecenderungan Compulsive Buying secara Online dengan menambahkan variabel-variabel lain. Hal lain adalah jumlah responden yang di jadikan sampel penelitian masih relatif lebih kecil dibandingkan dengan jumlah mahasiwa secara keseluruhan pada Universitas Mataram, atau mengambil sampel responden di luar kalangan mahasiswa. Terakhir adalah tidak dibatasi pada kategori produk tertentu seperti fashion saja, tetapi menggunakan kategori produk yang lebih beragam sehingga hasil yang diperoleh lebih bervariatif sehingga dapat 
dibandingkan khususnya berkaitan dengan Impulsive Buying dan Kecenderungan Compulsive Buying secara Online.

\subsubsection{Arah Penelitian Kedepan}

Diharapkan kepada peneliti-peneliti selanjutnya untuk dapat memperluas dan mengkaji secara lebih lanjut terkait variabel Sifat Materialisme, Motivasi Hedonik terhadap Impulsive Buying dan Kecederungan Compulsive Buying secara Online, Ini di karenakan kajian terkait hal tersebut di Indonesia sendiri masih sangat terbatas hal ini senada dengan pendapat yang dikemukkan oleh Prawira, (2015) yang menyatakan bahwa di Indonesia sendiri masih sangat sedikit penelitian terkait impulsive buying secara Online dikaitkan dengan psikologis konsumen. Selain itu, hasil penelitian yang menunjukkan adanya pengaruh yang tidak signifikan antara motivasi hedonik terhadap kecenderungan impulsive buying sehingga masih diperlukan kajian secara lebih lanjut oleh penelitian selanjutnya dengan menambahkan variabel pendapatan responden sebagai variabel kontrol, ini di karenakan salah satu alasan konsumen tidak melakukan impulsive buying secara Online adalah karena faktor keterbatasan pendapatan sehingga menyebabkan responden dalam penelitian ini relatif akan berbelanja Online jika barang yang ingin dibeli jika dibutuhkan saja.

\section{DAFTAR PUSTAKA}

Banu, S., Yasin, N, M., and Quoquab, (2013). "Compulsive Buying Behavior Among Young Malaysian Consumer. Worl Reviev Of Bussiness Research."Vol. 3, No, 2 pages 141-154.

Belk, R. W. (1989). "Materialism: Trait Aspects of Living in the Material World." Journal of Consumer Research, 12(3), pp: 256-280.

Case, T., Burns, O. M., and Dick, G. N. (2001). "Drivers Of On-Line Purchasing Among U.S. University Students". Proceedings of the 7th.

Cen Lu dkk, (2015). "Pengaruh Parent-Child Relationship Terhadap Compulsive Buying: Self-Esteem Sebagai Variabel Mediasi". Fakultas Ekonomi Universitas Kristen Marananta Bandung. ISSN: 2252-6749 Volume 4/Nomor 2/ Agustus 2015.

Chandra dkk, (2011). "Pengaruh Jenis Kelamin, Promosi Penjualan Dan Sifat Materialisme Terhadap Perilaku Impulse Buying Secara Online". Fakultas Ekonomi dan Bisnis Universitas Udayana (Unud). Bali, Indonesia.

Cuneyt, K. Gautam, B. (2004). "The Impacts Of Quickness, Price, Payment Risk, And Delivery Issues On On-Line Shopping". Journal of Socio-Economics, Vol.33, PP.241-251.

Dita Sari, V., (2014). "Pengaruh Materialism Happiness, Materialism Centrality Dan Materialism Success Terhadap Impulsive Buying Behavior Dan Efeknya Pada Compulsive Buying Behavior", Skripsi, Fakultas Ekonomi Universitas Atma Jaya Yogyakarta.

Dittmar, H. (2005). "A New Look At Compulsive Buying: Self Discrepancies And Materialistic Values As Predictors Of Compulsive Buying Tendency."Journal of Social and Clinical Psychology, 24: 832-859.

Ferdinand, Augusty T. (2014). "Metode Penelitian Manajemen". Edisi V. Semarang: Bp Undip

Floh, A. and Medlberger, M. (2013). "The Role of Atmospheric Cues In Online- Impulse Buying Behavior", Electronic Commerce Research and Applications. 12(1), 45-439. 
Fornell, C. and Larcker, D.F. (1981). "Evaluating Structural Equation Models With Unobservable Variables And Measurement Error', Journal of Marketing Research, Vol. 18, No. 1, pp.39-50.

Gerlach, Alexander L. dkk (2015)."Impulsivity In Consumers With High Compulsive Buying Propensity". Journal of Obsessive-Compulsive and Related Disorders. Institute of Clinical Psychologyand Psychotherapy Department of Psychology Germany.

Glatt, M.M., \& Cook, C. (1987). "Pathological spending as a form of psychological dependence." British Journal of Addiction, 82: 1257-1258.

Gupta, Shruti. 2013. "A Literature Of Compulsive Buying-Marketing Perpective". Journal Of Applied Business And Economic.Vol.14.O.6.

Hair, JF,.Anderson, R.E, Tatham, R.L dan Black. W.C. (1998). "Multivariate Data Analysis." 5 th Edition, New Jersey; Prentice Hall.

Hair, JF,. Anderson, R.E, Babin,. J.B., dan Black. W.C. (1998). "Multivariate Data Analysis.' "7th Edition, New Jersey; Prentice Hall.

https://kominfo.go.id/content/ detail/4286/ pengguna -internet Indonesia-nomor-enam- dunia/0/ sorotan_media., Harian Kompas Di Unggah 24 November 2014 Di Aksess Pada 20 Januari 2017.

http:// presidenri.go.id/topik-aktual / membuka-dan-mengembangkan-potensi-e- commerce-diindonesia.html. Di akses pada bulan November 2016.

https://id.wikipedia.org/wiki/Materialisme. Di Unggah pada 13 Juni 2016 Di akses pada 20 Januari 2017.

http://www.nielsen.com/id/en/press-room/2014/konsumen indonesia mulai menyukai belanjaonline.html diunggah oleh Miladinne Lubis 09-03-2014. Diakses oleh penulis tanggal 21 Feb. 17.

Jeffrey, S.A. and Hodge, R. (2007)."Factors Influencing Impulse Buying During an Online Purchase. Research, 7 (1). 367-379.

Kharis, I. F., (2006). "Studi Mengenai Impulse Buying Dalam Penjualan Online" (Studi Kasus di Lingkungan Universitas Diponegoro Semarang).

Krisjanto, Prabowo, (2010). "Analisis Perilaku Pembelian Compulsive di HyperMarket. Studi Empiris Pada Mahasiswa FE Universitas Atmajaya Yogyakarta.

Latan, Hengky, (2013). "Model Persamaan Struktural, Teori dan Implementasi AMOS 21". Penerbit AlfaBeta Bandung.

Lina. (2015). "Pengaruh Hedonic Shopping Motivations Terhadap Impulse Buying Behavior Penlitian in Pada Yogya Dan Ramayana Department Store Garut." Fakultas Ekonomi Universitas Garut. Jurnal Wacana Ekonomi Universitas Garut ISSN: 1412-5897. Jurnal Wacana Ekonomi Universitas Garut Vol. 13; No. 03; 2015; $1-8$.

Lizamary dkk, (2014). "Analisa Pengaruh Hedonic Shopping Value Terhadap Impulse Buying Dengan Shopping Lifestyle Dan Positive Emotion SebagaiVariabel Intervening Pada Mall Ciputra World Surabaya." Universitas Kristen Petra Jl. Siwalankerto 121-131, Surabaya. Jurnal Manajemen Pemasaran, Vol. 8, No. 2, Oktober 2014 doi: 10.9744/ pemasaran.8.2.80-89 ISSN 1907-235X.

Lumintang (2013). "Pengaruh Hedonic Motives Terhadap Impulse Buying Melalui Browsing Dan Shopping Lifestyle. Pada Online Shop." Jurnal.

Mowen, J.C. \& Minor, M., (2002). "Consumer Behaviour" (5th Edition) Upper Saddle River: Pretience Hall, Inc. 
Naomi, P., Mayasari, I., (2009)."Faktor-Faktor Yang Mempengaruhi Siswa SMA Dalam Perilaku Pembelian Kompulsif Perspektif Psikologi." Jurnal Manajemen dan Bisnis, Vol. 3, No. 2.

O'Guinn, T.C. and Faber, R. J. (1989). "Compulsive Buying: A Phenomenological Exploration." Journal of Consumer Research, $16 \quad$ (2), 147-157.

Overby, Jeffrey W, Lee, (2006). "The Effects Of Utilitarian and Hedonic Online Shopping Value on Consumer Preference and Intentions". International Journal of Science Direct.

Paramita dkk. (2015)."Pengaruh Motivasi Belanja Hedonik Terhadap Pembelian Impulsif Konsumen Matahari Surabaya." Sekolah Tinggi Ilmu Ekonomi Indonesia (STIESIA)."Jurnal Ilmu dan Riset Manajemen Volume 4, Nomor 1, Januari 2015.

Prawira dkk (2015). "Peran Motivasi Hedonis Memediasi Pengaruh Sifat Materialisme Terhadap Perilaku Pembelian Impulsif Secara Online". Fakultas Ekonomi dan Bisnis Udayana, Bali - Indonesia.

Podoshen, J.S., and Andrzejewski, S.A..(2012). "An Examination of the Relationships Between Materialisme, Conspicuous Consumption, Impulse Buying, and Brand Loyalty." Journal of Marketing Theory and Practice, 20(3).pp:319-333.

Richins, M. and Dawson, S. (1992). "A Consumer Values Orientation for Materialism and It's Measurement": Scale Development and Validation. Journal of Consumer Research, 19(3), 303-316.

Rook, D.W., dan R.J Fisher. (1998). "Normative Influences on Impulse Buying Behavior, Journal of Consumer Research," Vol: 22 (3), pp: 305-313.

Sari Kartika. (2013). "Pengaruh Kontrol Diri, Motivasi Dan Materialisme Terhadap Perilaku Pembelian Kompulsif (Survei Mahasiswa Universitas Muhammadiyah Purworejo)".

Soliha, Euis. (2010). "Pengaruh Self Acceptance Importance, Affiliation Importance, dan Community Feeling Importance Terhadap Compulsive Buying." Jurnal Siasat Bisnis, Vol. 14, No. 1, h:19-26.

Sun, T. and G. Wu. (2011). "Trait Predictors of Online Impulse Buying Tendency: A Hierarchial Approach." Journal of Marketing Theory and Practice, 19(3), pp: 337-346.

Turkyilmaz, Sakir Erdem, Aypar Uslu (2015). "The Effects of Personality Traits EWebsite Quality on Online Impulse Buying." International Conference on Strategic Innovative Marketing Madrid, Spain. Marmara University. Bahcelievler/Istanbul, 34180, Turkey.

Utami, R..U. (2011). "Pengaruh Family Strukture Terhadap Materialisme Dan Pembelian Compulsive Buying Pada Remaja." Jurnal Teori Dan Terapan 1 Tahun 4, No. 3, Hal 63- 75.

Wijanto, Setyo H. (2008). "Structure Equation Modeling dengan Lisrel.8.8." Yogyakarta; Graha Ilmu.

Widya, Kartika, Gilang, (2012). "Analisis Pengaruh Hedonic Value dan UtilitarianValue Terhadap Keputusan Konsumen dan Behavior Intention Pada Industri Fast Casual Restaurant. Jakarta, Fakultas Ekonomi Program Magister Manajemen, Univesitas Indonesia.

Www. Money. Id/digital /2016 - transaksi - ecommerce -di-Indonesia - tembus-68 triliunrupiah-160410k. htm. Di Aksess 20 Januari 2017.

Zikmund, W.G.(2003).'Bussiness Research Metdhods". 7th Edition. Thomshon South Western, United States of America. 